\title{
Colonization of America by Drosophila subobscura: Association between Odh gene haplotypes, lethal genes and chromosomal arrangements
}

\author{
Francesc Mestres ${ }^{1 *}$, Laura Abad $^{1}$, Beatriz Sabater-Muñoz ${ }^{2}$, \\ Amparo Latorre ${ }^{2}$ and Luís Serra ${ }^{1}$ \\ ${ }^{1}$ Departament de Genètica, Universitat de Barcelona, 08071 Barcelona, Spain \\ ${ }^{2}$ Institut Cavanilles de Biodiversitat i Biologia Evolutiva, Universitat \\ de València, P.O. Box 2085, 46071 València, Spain
}

(Received 6 May 2004, accepted 18 July 2004)

\begin{abstract}
The colonization of America by Drosophila subobscura has been a unique experiment in nature that has allowed us to explore the effects of evolution on a continental scale. To analyze this evolutionary event, nucleotide sequences of the Odh (Octanol dehydrogenase) gene were obtained for 43 lethal chromosomal lines from colonizing populations of North America and 5 from South America, in addition to 5 chromosomal lines from Europe with different viabilities and 2 from laboratory marker stocks. Since 10 different Odh haplotypes were found in America, the minimum number of colonizers would be 5 (or 3 mated females). Only one Odh haplotype was found in American $\mathrm{O}_{5}$ inversions confirming that only one copy of this inversion was included among the sample of colonizers. The same Odh haplotypes were detected in association with the same chromosomal arrangements and with identical lethal genes in both North and South America indicating that exactly the same chromosome types reached both hemispheres. These observations indicate that the two continental colonizations are not independent. They are derived from the same colonization event. The population from which the colonization started should contain the $\mathrm{O}_{5}$ inversion, a non-negligible frequency of the $\mathrm{O}_{3+4+7}$ arrangement and all other arrangements found in America. So far the only populations that fulfill all these requirements are those from Greece, indicating that these populations can be considered good candidates as a starting point for an in depth analysis of the origin of the American colonization by D. subobscura.
\end{abstract}

Key words: chromosomal arrangements, colonization, Drosophila subobscura, lethal genes, $O d h$

\section{INTRODUCTION}

It is rare to have the opportunity to study the evolutionary consequences of recent colonization events. Drosophila subobscura previously considered to be a species with a Palearctic distribution, was first detected in Puerto Montt (Chile) in 1978 (Brncic et al. 1981). It spread rapidly throughout Chile and can now be found from La Serena to Punta Arenas (Prevosti et al. 1989). In 1982 D. subobscura was also found in Port Townsend (Washington, USA) (Beckenbach and Prevosti 1986). Its present distribution include the Western states of the USA and Canada from Port Hardy (British Columbia, Canada) (Huey et al. 2000) to Ojai (California) (Prevosti

Edited by Hidenori Tachida

* Corresponding author. E-mail: fmestres@ub.edu et al. 1989). This double colonization is a grand experiment of evolution with two replicates (Ayala et al.1989) that has allowed the predictable character of evolution and its speed to be analyzed. Analysis of chromosomal polymorphism has shown the rapid appearance of latitudinal clines in both North and South America that converge on those detected in the Old World (Prevosti et al. $1985 ; 1988 ; 1990)$. Clinal variation of other traits also converges on the pattern found in Old World flies. For example, although no wing-size cline was evident in North or South America one decade after the colonization (Pegueroles et al. 1995), after two decades a significant cline was evident in North American populations (Huey et al. 2000; Gilchrist et al. 2001).

Among the different genetic levels analyzed (Prevosti et al. 1983; Latorre et al. 1986; Rozas et al. 1990; Rozas and Aguadé 1991; Balañà et al.1994; Pegueroles et al. 1996; 
1999; Noor et al. 2000; Pascual et al. 2001), one that has provided very valuable information on the colonization event has been that of lethal genes. These genes can only be studied for the $\mathrm{O}$ chromosome of $D$. subobscura, because this is the only one for which a balanced-lethal strain exists: $V a / B a$ (Varicose/Bare) (Sperlich et al. 1977). In American populations lethal genes do not distribute at random among the different chromosomal arrangements (Mestres and Serra 1999), in some cases being significantly associated with particular arrangements. This is the case for the complete association observed between the $\mathrm{O}_{5}$ inversion and a lethal gene and for the partial association between the $\mathrm{O}_{3+4+7}$ chromosomal arrangement and another lethal gene (Mestres et al. 1990; 1992; 1995; Solé et al. 2000). These associations were found in both North and South American populations suggesting that the colonizations were not independent (Mestres et al. 1992). Furthermore, the lethal genes have persisted in time, revealing a possible heterotic effect of these inversions (Mestres et al. 2001). As the $\mathrm{O}_{5}$ inversion is not very common and has a rather erratic distribution in the Old World (Loukas and Krimbas 1980; Krimbas, 1993; Mestres et al. 1994; Zivanovic and Mestres 2000), it is likely that only one $\mathrm{O}_{5}$ inversion (carrying the lethal gene) was included in the initial sample of colonizers (Mestres and Serra 1995). The significant latitudinal clines of the frequency of this inversion observed in colonizing populations (Prevosti et al. 1985; $1988 ; 1990)$ together with its complete association with a lethal gene (Mestres et al. 1990; 1992; 1995, Solé et al. 2000) and its significant persistence in America (Mestres et al. 2001), make it especially suitable to study not only the origin of the colonization, but also some of the evolutionary consequences of this event.

As suggested by the distribution of genes in D. melanogaster (Lindsley and Zimm 1992) we deduced that the Odh (Octanol dehydrogenase) gene could be located inside and very close to the proximal breakpoint of the $\mathrm{O}_{5}$ inversion. Its location in D. subobscura has been confirmed in the present research using the in situ hybridization technique. Nucleotide sequences for $O d h$ were obtained for different $\mathrm{O}_{5}$ chromosomal lines from Europe and America, as well as in other lines with different chromosomal arrangements in order to analyze the relationship between the haplotypes and inversions. To date seven different arrangements have been detected in American populations $\left(\mathrm{O}_{\mathrm{st}}, \mathrm{O}_{5}, \mathrm{O}_{7}, \mathrm{O}_{3+4}, \mathrm{O}_{3+4+2}, \mathrm{O}_{3+4+7}\right.$ and $\mathrm{O}_{3+4+8}$ ) (Prevosti et al. $1985 ; 1988 ; 19 \overline{90}$ ). The O chromosome is usually divided into two regions: Segment I (about $1 / 3$ of the total $O$ chromosome length) covers the area in which arrangement $\mathrm{O}_{3+4}$ is located and segment II (about $2 / 3$ of the whole chromosome) corresponds to the remainder of the chromosome (Krimbas 1993). The Odh gene is located in segment II, and is included in the $\mathrm{O}_{7}$ and $\mathrm{O}_{5}$ inversions. This gene is close (5 chromosomal sections) to the proximal point of the $\mathrm{O}_{2}$ inversion. In all other situations the Odh gene could freely recombine. The rich chromosomal polymorphism of $D$. subobscura and the founder event of the American colonization could generate different kinds of associations. Associations between molecular markers and inversions have been studied in different species of the genus Drosophila (for a complete review see Andolfatto et al. 2001), including $D$. subobscura (Rozas and Aguadé 1994; Rozas et al. 1999; Munté et al. 2000).

In addition to the adaptive changes that have taken place in the American populations since the beginning of the colonization (Prevosti et al. 1985; 1988;1990; Huey et al. 2000; Gilchrist et al. 2001), there are some basic questions which demand explanations. One of them is to estimate the initial number of colonizers, and to ascertain which Palearctic population colonizers came from. Another related topic is the attempt to track the chromosomes or chromosomal fragments that were included within the initial sample of flies. Finally, an in depth study of the genetic relationship between North and South American populations has to be carried out. All these basic questions can be approached with the information obtained in this work using the nucleotide haplotypes of the Odh gene and the lethal genes as genetic markers of the chromosomal inversions, with which they are associated.

\section{MATERIALS AND METHODS}

Chromosomal lines sequenced All chromosomal lines with their arrangements in which the Odh gene has been sequenced are described in Table 1. Most of them are lethal chromosomal lines from three North American localities: Gilroy (California), Bellingham and Centralia (Washington). They were obtained with appropriate genetic crosses using the balanced-lethal strain $V a / B a$. These crosses have been described in detail elsewhere (Mestres et al. 1990; 1992; 1995). The Gilroy population was sampled in two different periods denoted as Gilroy I (1984 - 1985) (Mestres et al. 1990) and Gilroy II (1990 1991) (Mestres et al. 1992). Eleven lethal chromosomal lines were sequenced in Gilroy I and 8 in Gilroy II. The Bellingham collection was obtained in 1991 (Mestres et al. 1995) and 13 lethal chromosomal lines have been analyzed. The Centralia population was sampled in 1995 (Solé et al. 2000) and 11 lethal chromosomal lines have been sequenced. Furthermore, two lethal chromosomal lines (both carrying the $\mathrm{O}_{5}$ inversion) from the Chilean population of Puerto Montt (Mestres et al. 1990) and 3 from Santiago de Chile (Mestres et al. 1992) were analyzed. Although it is difficult to find the $\mathrm{O}_{5}$ inversion in European populations, some $\mathrm{O}_{5}$ chromosomal lines were sequenced: T15, a lethal line from the French population of Taulé (Mestres et al. 1992); L25, a semilethal 
Table 1. Description of all chromosomal lines that have been sequenced for the Odh gene.

\begin{tabular}{|c|c|c|c|c|c|}
\hline Chromosomal line & Arrangement & Viability & Population & Country & Accession number \\
\hline G7A & $\mathrm{O}_{5}$ & LCL & Gilroy I & U.S.A. & AJ496667 \\
\hline G32 & $\mathrm{O}_{3+4+2}$ & LCL & Gilroy I & U.S.A. & AJ496668 \\
\hline G34 & $\mathrm{O}_{3+4+2}$ & LCL & Gilroy I & U.S.A. & AJ496669 \\
\hline G39 & $\mathrm{O}_{3+4+7}$ & LCL & Gilroy I & U.S.A. & AJ496670 \\
\hline G41 & $\mathrm{O}_{3+4+7}$ & LCL & Gilroy I & U.S.A. & AJ496671 \\
\hline G61 & $\mathrm{O}_{5}$ & LCL & Gilroy I & U.S.A. & AJ496672 \\
\hline G66 & $\mathrm{O}_{3+4+2}$ & LCL & Gilroy I & U.S.A. & AJ496673 \\
\hline G209 & $\mathrm{O}_{3+4+7}$ & LCL & Gilroy I & U.S.A. & AJ496674 \\
\hline G215 & $\mathrm{O}_{3+4}$ & LCL & Gilroy I & U.S.A. & AJ496675 \\
\hline G226 & $\mathrm{O}_{5}$ & LCL & Gilroy I & U.S.A. & AJ496676 \\
\hline G240 & $\mathrm{O}_{5}$ & LCL & Gilroy I & U.S.A. & AJ496677 \\
\hline FGF5 & $\mathrm{O}_{3+4+7}$ & LCL & Gilroy II & U.S.A. & AJ496678 \\
\hline GM4 & $\mathrm{O}_{5}$ & LCL & Gilroy II & U.S.A. & AJ496679 \\
\hline GM24 & $\mathrm{O}_{3+4+2}$ & LCL & Gilroy II & U.S.A. & AJ496680 \\
\hline GM107 & $\mathrm{O}_{3+4+2}$ & LCL & Gilroy II & U.S.A. & AJ496681 \\
\hline GM111 & $\mathrm{O}_{3+4+7}$ & LCL & Gilroy II & U.S.A. & AJ496682 \\
\hline GM121 & $\mathrm{O}_{3+4+7}$ & LCL & Gilroy II & U.S.A. & AJ496683 \\
\hline GF3I & $\mathrm{O}_{3+4+2}$ & LCL & Gilroy II & U.S.A. & AJ496684 \\
\hline GM1BK & $\mathrm{O}_{3+4+7}$ & LCL & Gilroy II & U.S.A. & AJ496685 \\
\hline BM1 & $\mathrm{O}_{\mathrm{st}}$ & LCL & Bellingham & U.S.A. & AJ496686 \\
\hline BM2 & $\mathrm{O}_{5}$ & LCL & Bellingham & U.S.A. & AJ496687 \\
\hline BM5 & $\mathrm{O}_{\mathrm{st}}$ & LCL & Bellingham & U.S.A. & AJ496688 \\
\hline BM41 & $\mathrm{O}_{3+4+8}$ & LCL & Bellingham & U.S.A. & AJ496689 \\
\hline BM42 & $\mathrm{O}_{5}$ & LCL & Bellingham & U.S.A. & AJ496690 \\
\hline BM63 & $\mathrm{O}_{5}$ & LCL & Bellingham & U.S.A. & AJ496691 \\
\hline BM79 & $\mathrm{O}_{5}$ & LCL & Bellingham & U.S.A. & AJ496692 \\
\hline BM90 & $\mathrm{O}_{5}$ & LCL & Bellingham & U.S.A. & AJ496693 \\
\hline BF8 & $\mathrm{O}_{5}$ & LCL & Bellingham & U.S.A. & AJ496694 \\
\hline BF20 & $\mathrm{O}_{\mathrm{st}}$ & LCL & Bellingham & U.S.A. & AJ496695 \\
\hline BF30 & $\mathrm{O}_{5}$ & LCL & Bellingham & U.S.A. & AJ496696 \\
\hline BF66 & $\mathrm{O}_{3+4+2}$ & LCL & Bellingham & U.S.A. & AJ496697 \\
\hline BF69 & $\mathrm{O}_{\mathrm{st}}$ & LCL & Bellingham & U.S.A. & AJ496698 \\
\hline C6B & $\mathrm{O}_{3+4}$ & LCL & Centralia & U.S.A. & AJ496699 \\
\hline $\mathrm{C} 21 \mathrm{H}$ & $\mathrm{O}_{3+4+8}$ & LCL & Centralia & U.S.A. & AJ496700 \\
\hline C22A & $\mathrm{O}_{5}$ & LCL & Centralia & U.S.A. & AJ496701 \\
\hline C57B & $\mathrm{O}_{5}$ & LCL & Centralia & U.S.A. & AJ496702 \\
\hline $\mathrm{C} 61 \mathrm{E}$ & $\mathrm{O}_{5}$ & LCL & Centralia & U.S.A. & AJ496703 \\
\hline C66D & $\mathrm{O}_{3+4+8}$ & LCL & Centralia & U.S.A. & AJ496704 \\
\hline C93B & $\mathrm{O}_{3+4+8}$ & LCL & Centralia & U.S.A. & AJ496705 \\
\hline C94B & $\mathrm{O}_{3+4+8}$ & LCL & Centralia & U.S.A. & AJ496706 \\
\hline $\mathrm{C} 105 \mathrm{~J}$ & $\mathrm{O}_{5}$ & LCL & Centralia & U.S.A. & AJ496707 \\
\hline C110N & $\mathrm{O}_{5}$ & LCL & Centralia & U.S.A. & AJ496708 \\
\hline C185I & $\mathrm{O}_{3+4+8}$ & LCL & Centralia & U.S.A. & AJ496709 \\
\hline P282 & $\mathrm{O}_{5}$ & LCL & Puerto Montt & Chile & AJ496710 \\
\hline P269 & $\mathrm{O}_{5}$ & LCL & Puerto Montt & Chile & AJ496711 \\
\hline $\mathrm{S} 16$ & $\mathrm{O}_{3+4+2}$ & LCL & Santiago de Chile & Chile & AJ496712 \\
\hline S47 & $\mathrm{O}_{5}$ & LCL & Santiago de Chile & Chile & AJ496713 \\
\hline S49 & $\mathrm{O}_{3+4+7}$ & LCL & Santiago de Chile & Chile & AJ496714 \\
\hline $\mathrm{T} 15$ & $\mathrm{O}_{5}$ & LCL & Taulé & France & AJ496715 \\
\hline L25 & $\mathrm{O}_{5}$ & SLCL & Lilla-Edet & Sweden & AJ496716 \\
\hline LNF21 & $\mathrm{O}_{5}$ & NCL & Louvain-la-Neuve & Belgium & AJ496717 \\
\hline C31 & $\mathrm{O}_{3+4+8+7}$ & LCL & Bordils & Spain & AJ496718 \\
\hline F122 & $\mathrm{O}_{3+4+22}$ & NCL & Observatori Fabra & Spain & AJ496719 \\
\hline chcu & $\mathrm{O}_{3+4}$ & HCL & Laboratory strain & - & AJ496720 \\
\hline $\mathrm{Va}$ & $\mathrm{O}_{3+4+\mathrm{VIII}+210}$ & BLC & Laboratory strain & - & AJ496721 \\
\hline
\end{tabular}

LCL stands for "lethal chromosomal line', SLCL "semilethal chromosomal lines", NCL "normal chromosomal line", HCL "homokaryotypic chromosomal line" and BLC "balancer lethal chromosome". 
line from the Swedish population of Lilla Edet (Mestres et al. 1992); and LNF21, a line with normal viability and maintained in homokaryotypic $\mathrm{O}_{5} / \mathrm{O}_{5}$ condition from the Belgian population of Louvain-la-Neuve, obtained from a 1999 sample.

Finally, we studied the F122 homokaryotypic chromosomal line $\left(\mathrm{O}_{\underline{4+3}+22} / \mathrm{O}_{\underline{3+4+22}}\right)$. The $\mathrm{O}_{22}$ inversion has very similar breakpoints to those of the $\mathrm{O}_{5}$. It was obtained in a collection from Observatori Fabra (Barcelona) (Mestres et al. 1998). A lethal chromosomal line (C31) with the very infrequent arrangement $\mathrm{O}_{3+4+8+7}$ from the Bordils population (about $90 \mathrm{~km} \mathrm{NE}$ of Barcelona) (Mestres et al. 1990) was also sequenced. In addition, the sequences of the $O d h$ gene of the laboratory stock chromosomes $V a$ and chcu were obtained.

In situ hybridization on polytene chromosomes Polytene chromosome squashes were prepared from $D$. subobscura individuals of the homokaryotypic $\left(\mathrm{O}_{\underline{3+4}} / \mathrm{O}_{3+4}\right)$ chculchcu (cherry curled) strain using the procedure described by Visa et al. (1991). The DNA probe was obtained from $D$. melanogaster (Luque et al. 1994) and was labeled with digoxigenin-dUTP (Roche Diagnostics nick translation kit). Hybridization and detection were carried out using the procedures described by de Frutos et al. (1990), with reagents from the digoxigenin-nucleic acid detection kit (Roche Diagnostics).

Strains and DNA preparation Isolation of total DNA from a single individual was carried out according to the method of Latorre et al. (1986).
PCR cloning and sequencing Two sets of degenerate primers (C1-CD6 and C2-CD4) were designed based on the sequence of $D$. melanogaster Odh (accession number UO7641). The conserved regions for the design of the primers were chosen based on the alignment of amino acid sequences of this gene from several species (Luque et al. 1994) (Fig. 1).

PCR reactions were performed using the GeneAmp 2400 System (Perkin Elmer). Cycling conditions were $94^{\circ} \mathrm{C}$ for $5 \mathrm{~min} ; 35$ cycles of $94^{\circ} \mathrm{C}$ for $10 \mathrm{~s}, 55^{\circ} \mathrm{C}$ for $30 \mathrm{~s}$, $72^{\circ} \mathrm{C}$ for $1 \mathrm{~min}$; and a final extension of $4 \mathrm{~min}$ at $72^{\circ} \mathrm{C}$. PCR reactions contained 200mM dNTPs (AP Biotech), 20 pmol of each set of primers, $1 \mathrm{x}$ Taq buffer, $1.5 \mathrm{u}$ of Taq polymerase (AP Biotech) and 10 to $40 \mathrm{ng}$ of template in a final volume of $50 \mu$ l.

The PCR fragments (264 bp for C1-CD6 and $800 \mathrm{bp}$ for $\mathrm{C} 2-\mathrm{CD} 4)$ of several strains were excised from a $1.4 \%$ agarose gel in 0.5xTBE and extracted using the GFX ${ }^{\mathrm{TM}}$ PCR DNA and Gel Band Purification kit (AP Biotech). PCR products were cloned into T-pBluescript $\mathrm{sk}(+)$ (Stratagene), prepared as in Marchuk et al. (1992) and transformed into $E$. coli XL1-Blue MRF' (Stratagene). Plasmid DNA extractions were carried out using the CONCERT $^{\mathrm{TM}}$ Rapid miniprep system (Gibco-BRL). Sequencing reactions were performed in a PE/ABI 373 and 377 at the Servei de Seqüènciació of the Universitat de València, using the dRhodamine ABI PRISM Dye Terminator Cycle Sequencing Ready Reaction Kit (Perkin Elmer) and two primers (T7 and T3 pBluescript).

The sequences of these cloned fragments were used to design new internal primers (ODH-F, ODH-R, ODHseq-F

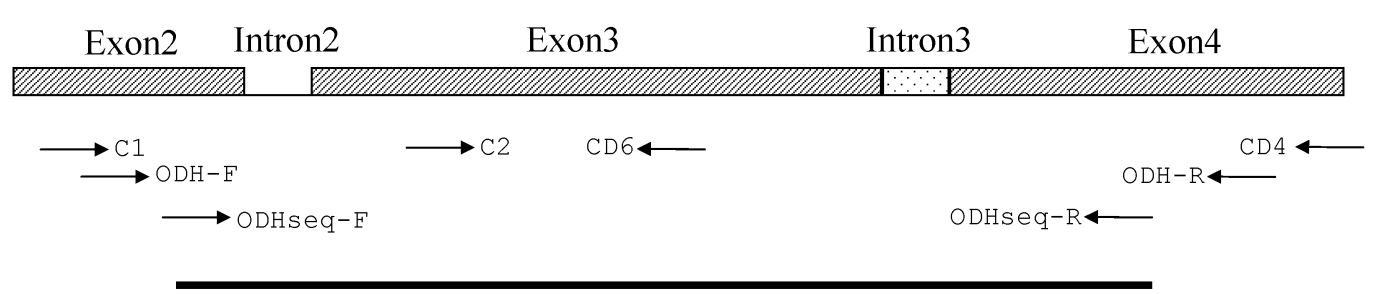

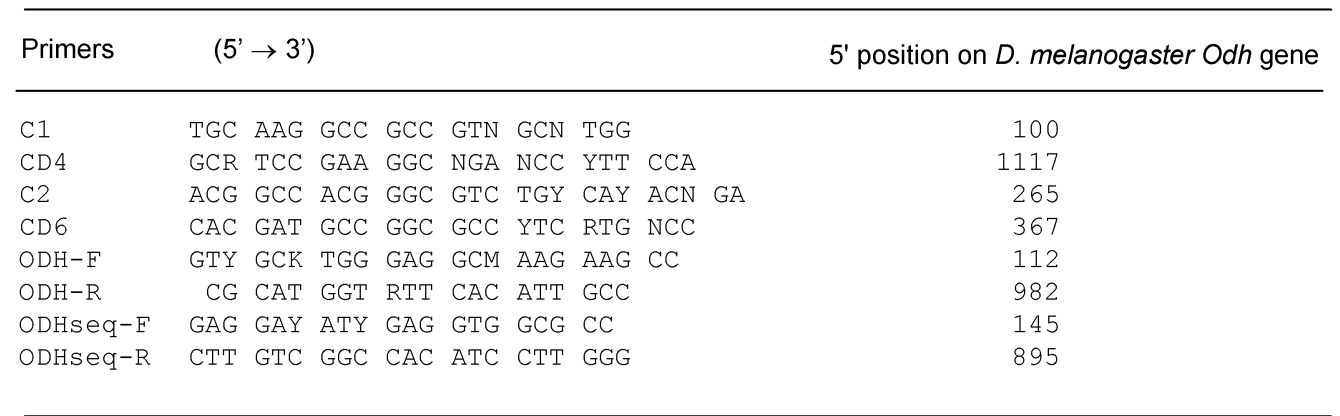

Fig. 1. Diagrammatic representation of the Odh gene fragment of D. subobscura. Arrows indicate the relative position of the primers. Intron 3 is not present in D. melanogaster (dotted box). Black line indicates the sequenced fragment, 793 nucleotides long. Nucleotides: exon 2, 60; intron 2, 65; exon 3, 462; intron 3, 51; exon 4, 155. 
and ODHseq-R, see Fig. 1) specific for D. subobscura Odh.

The procedure implies a first PCR with $\mathrm{C} 1$ and CD4 (PCR conditions as described above), followed by a nested PCR with ODH-F and ODH-R, using $1 \mu$ of first PCR as template for nested PCR. Cycling conditions for nested PCR were $94^{\circ} \mathrm{C}$ for $3 \mathrm{~min}$; 5 cycles of $94^{\circ} \mathrm{C}$ for $1 \mathrm{~min}, 58^{\circ} \mathrm{C}$ for $1 \mathrm{~min}, 72^{\circ} \mathrm{C}$ for $1 \mathrm{~min}$; 35 cycles of $94^{\circ} \mathrm{C}$ for $30 \mathrm{~s}, 60^{\circ} \mathrm{C}$ for $1 \mathrm{~min}, 72^{\circ} \mathrm{C}$ for $1 \mathrm{~min}$; and a final extension of $4 \mathrm{~min}$ at $72^{\circ} \mathrm{C}$. This PCR product was ethanol precipitated and direct sequenced using the internal primers $\mathrm{C} 2, \mathrm{CD} 6$, ODHseq-F and ODHseq-R (Fig. 1). Odh genes were sequenced on an ABI PRISM ${ }^{\mathrm{TM}} 377$ (Perkin Elmer) of the Servei de Seqüenciació Automàtica of the Universitat de Barcelona.

\section{Sequence alignment and phylogenetic analysis} Consensus sequence identification and assemblage of all readings of each clone was performed by analysis of the electropherograms with SEQUENCHER v3.0 (Genecodes co.). Sequence alignments were performed with BioEdit v. 4.8.6 (Hall 1999; http://www.mbio.ncsu.edu/BioEdit). DNA polymorphism was analyzed using DnaSP version 3 (Rozas and Rozas, 1999). The Kimura 2-parameter distance model and the Neighbor-Joining (NJ) tree reconstruction algorithm (Saitou and Nei 1987) were conducted using MEGA v. 2 (Kumar et al. 2001).

\section{RESULTS}

In situ hybridization Analysis of the in situ hybridization showed that the Odh gene is located within section $84 \mathrm{~B}$ of the $\mathrm{O}$ chromosome of D. subobscura according to the Kunze-Mühl and Müller map (1958). It is located in the homologous position of the D. melanogaster Odh (Luque et al. 1994), inside and very close to the proximal breakpoint of the $\mathrm{O}_{5}$ inversion. It is also located within the chromosomal inversions $\mathrm{O}_{7}$ (found in American populations), $\mathrm{O}_{1}$ and $\mathrm{O}_{22}$ (both absent in America), but outside $\mathrm{O}_{2}$ (a frequent inversion in America), close to its proximal breakpoint.

Analysis of the sequences 55 sequences of a 793 nucleotides fragment of $O d h$ were obtained. This fragment contains part of exon 2 , intron 2 , exon 3 , intron 3 and part of exon 4. Intron 3, 51 nucleotides long, is present in D. subobscura, but not in D. melanogaster. This intron, predicted by Southern blot (Luque et al. 1994) has been confirmed in the present research. The distribution of this intron in different evolutionary lineages is described by Canestro et al. 2001.

One of the main problems in the analysis of the sequences was to the fact that most of the chromosomal lines (51) were heterokaryotypic, carrying one $V a$ balancer chromosome and one wild type chromosome. Thus, two Odh alleles (one from each chromosome) were ampli- fied and sequenced together. It was essential to distinguish between the Odh allele of the Va chromosome and that of wild type. Fortunately, some individual Odh sequences were obtained by cloning in plasmids during the process of primers design. At least one of them was expected to belong to the $O d h$ gene of the $V a$ chromosome. Clear polymorphic sites were often detected in the chromatograms, in which one nucleotide belonged to the $O d h$ allele of the $V a$ chromosome. Comparing these positions with the individual sequences it was possible to identify the Odh allele of the $V a$ balancer chromosome and use it as reference in all analyses. No polymorphisms due to insertion/deletion were found, in either the exons or the introns.

Odh haplotypes in different chromosomal arrangements The pattern of polymorphisms of the Odh gene in different chromosomal arrangements is shown in Fig. 2. All $\mathrm{O}_{5}$ inversions from North and South America have the same Odh haplotype which confirms that only one of these inversions was carried by the sample of colonizers (Mestres and Serra 1995). The $\mathrm{O}_{5}$ inversions from Taulé (France) and Lilla-Edet (Sweden) have the same Odh haplotype as that found in America but the haplotype of the $\mathrm{O}_{5}$ inversion from Louvain-la-Neuve (Belgium) has four different substitutions. Nine lethal chromosomal lines with the $\mathrm{O}_{3+4+2}$ arrangement were sequenced, all of them presenting the same haplotype. The Odh gene is outside but close (about 8 chromosomal sections) to the proximal breakpoint of the $\mathrm{O}_{2}$ inversion. All these lines are lethal and out of 36 crossings performed some of them proved to be allelic (Mestres et al. 1992; 1995). Seven lines with the $\mathrm{O}_{3+4+7}$ arrangement (all carrying the same lethal gene) were sequenced. The $O d h$ gene is located inside the $\mathrm{O}_{7}$ inversion. In general, the haplotypes found in this arrangement have few polymorphism than those found in other arrangements. Two groups can be clearly distinguished: one corresponding to the haplotype found in chromosomal lines GM1BK, S49 and G209; the other corresponding to the haplotype found in chromosomal lines GM111, GM121, G39 and FGF5, which have the same non-synonymous substitution (position 509). The sequence of FGF5 differs from the others (GM111, GM121 and G39) by one substitution (position 167). All sequences analyzed in $\mathrm{O}_{3+4+7}$ chromosomal lines are likely to have a common origin because they lack some substitutions in the D. subobscura specific intron that are found in all other sequenced lines. These seven $\mathrm{O}_{3+4+7}$ chromosomal lines have the same lethal gene. Four different haplotypes were observed in the $\mathrm{O}_{\underline{3+4+8}}$ arrangement (located far away from the Odh gene). One of them (detected in the C185I line) is identical to that observed in the $\mathrm{O}_{3+4+2}$ chromosomes. The $\mathrm{C} 21 \mathrm{H}$ line has a haplotype identical to one detected in three $\mathrm{O}_{\mathrm{st}}$ lines. Finally, two more haplotypes were observed in the $\mathrm{O}_{\underline{3+4+8}}$ arrange- 


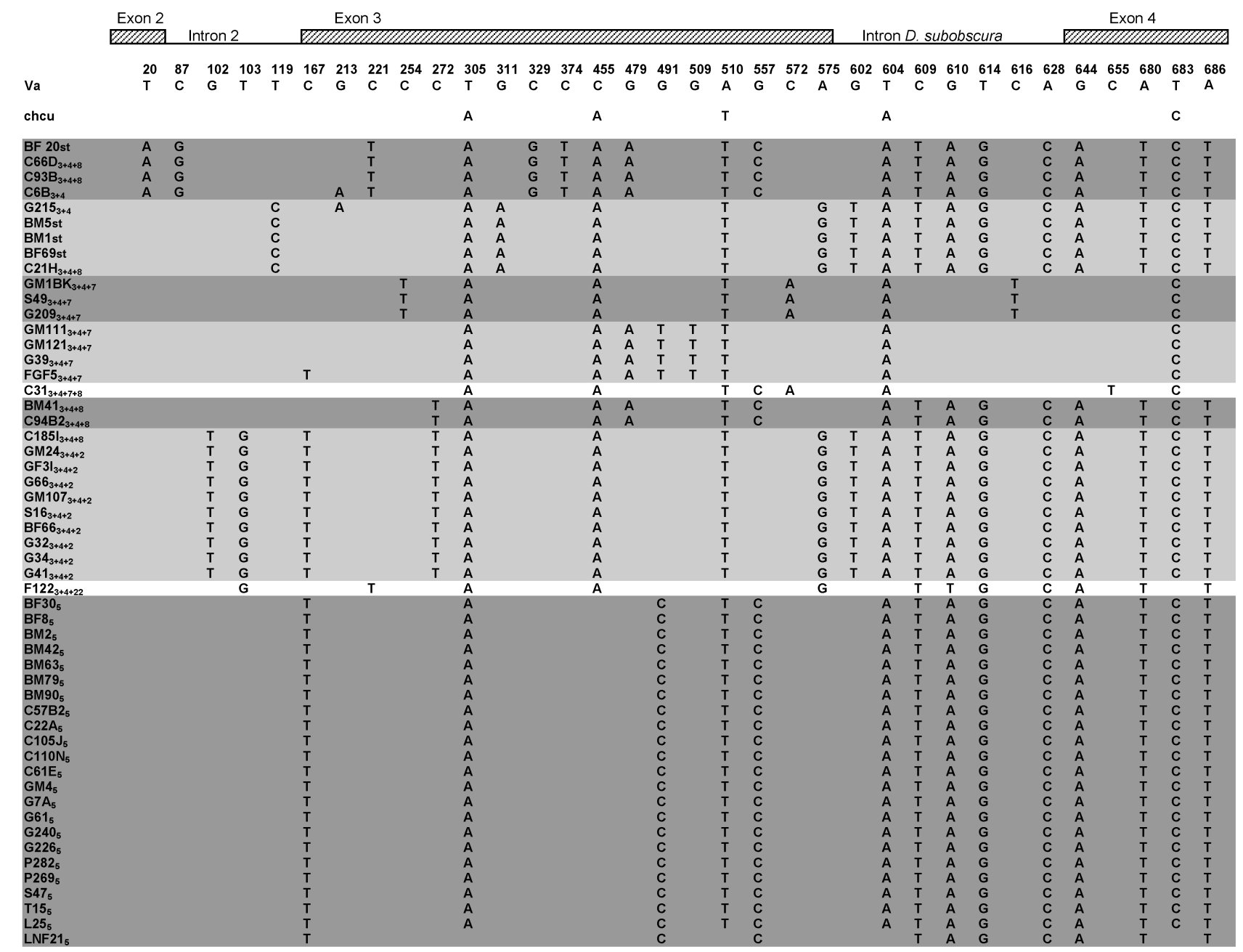

Fig. 2. Nucleotide polymorphisms detected in all chromosomal lines sequenced for the $O d h$ gene, using the $V a$ allele as reference.

ments, one in the C66D and C93B lines and the other in the BM41 and C94B2 lines. Only two lines with the $\mathrm{O}_{\underline{3+4}}$ arrangement were sequenced. In this case the $O d h$ gene is also located far away from the breakpoint of this arrangement. The two sequences are very different from each other, but the $\mathrm{C} 6 \mathrm{~B}$ line resembles lines $\mathrm{C} 93 \mathrm{~B}, \mathrm{C} 66 \mathrm{D}$ (both $\left.\mathrm{O}_{3+4+8}\right)$ and BF20 $\left(\mathrm{O}_{\text {st }}\right.$ ), and line G215 is very similar to lines BM5, BM1, BF29 (all $\left.\mathrm{O}_{\mathrm{st}}\right)$ and $\mathrm{C} 21 \mathrm{H}\left(\mathrm{O}_{3+4+8}\right)$. Four $\mathrm{O}_{\text {st }}$ chromosomal lines were sequenced, showing two allelic forms: one is detected in lines BM1, BM5 and $\mathrm{BF} 69$, being identical to that of line $\mathrm{C} 21 \mathrm{H}\left(\mathrm{O}_{3+4+8}\right)$; the other (BF20) is identical to that of C66D and C93B (both $\mathrm{O}_{3+4+8}$ ). The location of $\mathrm{Odh}$ in chromosomal lines $\mathrm{O}_{\underline{3+4}}$, $\mathrm{O}_{\underline{3+4+8}}$ and $\mathrm{O}_{\underline{s t}}$ allows the possibility of recombination and other forms of genetic exchange. The F122 line $\left(\mathrm{O}_{3+4+22}\right)$ shows a very different pattern of polymorphism to that of the $\mathrm{O}_{5}$ lines, although they have similar breakpoints (Kunze-Mühl and Müller 1958; Mestres et al. 1998), demonstrating an independent origin of the two inversions. Finally, the C31 line (carrying the uncommon arrangement $\mathrm{O}_{3+4+8+7}$ ) has a special haplotype. It resembles the
$\mathrm{O}_{\underline{3+4+7}}$ haplotypes more than those of $\mathrm{O}_{3+4+8}$, probably due

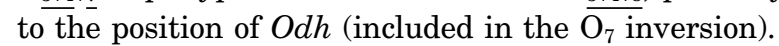

Table 2. Estimates of nucleotide polymorphism of Odh gene within different groups of arrangements. $n=$ number of sequences; Nhap = number of haplotypes; $h=$ haplotype diversity; $S=$ number of polymorphic sites; $\pi=$ nucleotide diversity; $\theta=$ expected average number of nucleotide differences; $k=$ average number of nucleotide differences.

\begin{tabular}{lcccc}
\hline \hline & \multicolumn{2}{c}{$\mathrm{O}_{5}$ and $\mathrm{O}_{3+4+7}$} & \multicolumn{2}{c}{$\begin{array}{c}\text { All other } \\
\text { arrangements }\end{array}$} \\
\hline$n$ & 27 & 21 & \\
Nhap & 4 & & & \\
$h \pm S D$ & 0.442 & \pm 0.109 & 0.743 & \pm 0.083 \\
$S$ & 17 & & 17 & \\
$\pi \pm S D$ & $0.00706 \pm 0.00160$ & $0.00807 \pm 0.00109$ \\
$\theta \pm S D$ (per site) & $0.00556 \pm 0.00216$ & $0.00596 \pm 0.00240$ \\
$k \pm S D$ & 5.595 & \pm 2.772 & 6.400 & \pm 3.158 \\
$\theta \pm S D$ (per sequence) & 4.411 & \pm 1.712 & 4.725 & \pm 1.903 \\
\hline
\end{tabular}


Regarding the Odh gene itself, we also studied its nucleotide polymorphism for the American lethal chromosomal lines, grouping them into two sets: those in which the Odh gene is located within an inversion $\left(\mathrm{O}_{5}\right.$ and
$\mathrm{O}_{3+4+7}$ ) and those in which it is not (all other chromosomal arrangements). The values of the parameters that describe this nucleotide polymorphism are shown in Table 2. The first group exhibits lower diversity than

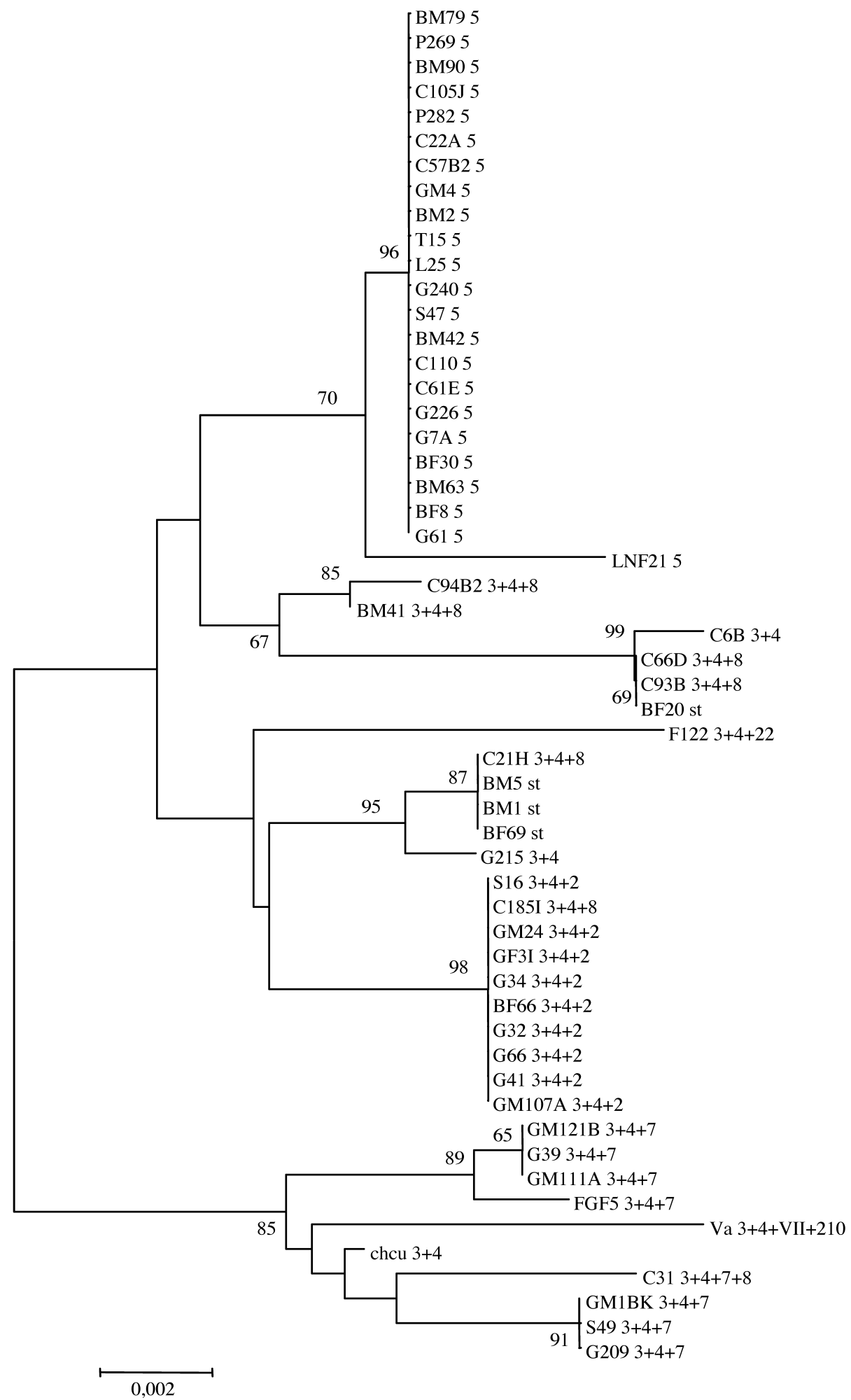

Fig. 3. Neighbor-joining phylogenetic tree obtained using all the Odh nucleotide sequences. A clear association between the nucleotide sequences and chromosomal arrangements can be observed. 
the second group (for haplotype diversity the SD ranges between the two groups do not overlap), probably due to the founder event and by the restriction of free interchange of genetic information.

A neighbor-joining phylogenetic tree was constructed to obtain an objective classification of the haplotypes according to their similarities (Fig. 3). A clear cluster is obtained for all $O d h$ sequences of the $\mathrm{O}_{5}$ inversion and for sequences in the arrangements $\mathrm{O}_{3+4+7}$ (including the sequences of the $V a$ and chcu chromosomes and the line $\mathrm{O}_{3+4+8+7}$ ) independently of their origin. The situation for the sequences in which the Odh gene is not included in any inversion $\left(\mathrm{O}_{\underline{3+4}}, \mathrm{O}_{\underline{3+4+2}}, \mathrm{O}_{\underline{3+4+8}}\right.$ and $\left.\mathrm{O}_{\mathrm{st}}\right)$ is less clear. Although all $\mathrm{O}_{3+4+2}$ are grouped together (as mentioned previously), Odh is outside of the inversion, but not far away (about 5 chromosomal sections) from the proximal breakpoint.

\section{DISCUSSION}

The similarity between North and South America Our analysis of the Odh gene confirms the high degree of genetic resemblance between North and South American populations previously demonstrated in other studies (Prevosti et al. 1988; 1989; Balanyà et al. 1994; Rozas and Aguadé 1991; Mestres et al. 1990; 1992; 1995; Solé et al. 2000). All $\mathrm{O}_{5}$ chromosomal lines have the same haplotype in both North and South America. Furthermore, other chromosomal lines carrying the same haplotype are also found in both continents: the Chilean line S49 $\left(\mathrm{O}_{3+4+7}\right)$ has the same haplotype as that observed in the Californian lines GM1BK and G209, which also carry the $\mathrm{O}_{3+4+7}$ arrangement (Fig. 2). The Chilean line S16 (carrying the $\mathrm{O}_{3+4+2}$ arrangement) has the same haplotype as that found in the $\mathrm{O}_{3+4+2}$ chromosomal lines from North America. Due to the founder event and the extraordinarily rich chromosomal polymorphism for inversions in this species, all levels of genetic variation (allozymes, lethal genes, nucleotide sequences) are usually associated to a greater or lesser degree with particular chromosomal arrangements in the American populations (Prevosti et al. 1983; 1989; Mestres et al. 1990; 1992; 1995; Mestres and Serra 1999), so the patterns of genetic variability observed will depend on the distribution of these inversions. Moreover, the lethal genes detected in these arrangements are allelic in North and South America. As mentioned above, American $\mathrm{O}_{5}$ inversions have the same haplotype for the Odh gene and the same lethal gene (Mestres et al. 1990; 1992; 1995; Solé et al. 2000). The Chilean line $\mathrm{S} 16\left(\mathrm{O}_{3+4+2}\right)$ and the North American lines carrying this arrangement have the same haplotype and some of these North American lines also have the same lethal gene found in the S16 line. A similar situation is observed in the Chilean line $\mathrm{S} 49\left(\mathrm{O}_{3+4+7}\right)$; it has the same haplotype, chromosomal arrangement and lethal gene as the Californian lines G209 and GM1BK. The same associations (chromosomal arrangements, lethal genes and Odh haplotypes) observed between North and South American populations suggest that at least some identical chromosomes carried by the sample of colonizers reached both hemispheres.

As both colonized areas are widely separated and there is no gene flow between them, it is most likely that in the first step of the colonization a rather small sample of colonizers reached one of the hemispheres. After that, a large sample of secondary colonizers should have reached the other hemisphere. There was no substantial loss of genetic variability in the second step, as revealed by the available genetic data (Prevosti et al. 1988; 1989; Mestres et al. 1992; Balanyà et al. 1994; Pascual et al. 2001). However, we still don't know which hemisphere was colonized first, or how the colonizers were carried to the colonized areas. It is also difficult to explain the fact that after 500 years of commercial contact between America and the Palearctic region $D$. subobscura has only recently reached the New World. Thus, we have a natural experiment with two replicates (North and South America), with a very similar initial genetic variability and almost equivalent pattern of climates. However, the evolutionary processes have not been identical in both colonized areas: the heterotic effect of the $\mathrm{O}_{5}$ inversion is different in both hemispheres (Mestres et al. 2001) and the frequency clines of some chromosomal arrangements with latitude have not undergone the same evolutionary trajectories in both hemispheres (Balanyà et al. 2003). There are likely to be important differences in both hemispheres with regard to some environmental conditions (physical and biological), for instance, there are other species of the obscura group in North America, but not in South America.

The number of colonizers Knowledge of the initial number of colonizers is a major topic, because it could indicate the magnitude of the founder effect (Brncic et al. 1981; Prevosti et al. 1985; Mestres et al. 1990; Rozas and Aguadé 1991; Pascual et al. 2001). In our study, ten different haplotypes were observed for the $O d h$ gene in the American lines. Thus, the minimum number of individuals necessary to "pack" all this genetic variation is 5 (or 3 mated females). This value is similar to that obtained by Rozas and Aguadé (1991) based on four-cutter restriction map analysis of the rp49 gene. Furthermore, as only one haplotype has been detected in all American $\mathrm{O}_{5}$ chromosomal inversions (which is completely associated with a lethal gene), the hypothesis that only one $\mathrm{O}_{5}$ inversion was included in the initial sample of colonizers is confirmed (Mestres and Serra 1995). Thus, due to the founder effect, all $\mathrm{O}_{5}$ inversions found in America are copies of the original inversion, which probably increased in frequency by genetic drift and natural selection (Mestres 
et al. 2001).

Gathering together the information obtained from different procedures, estimates of the initial number of colonizers range between 10 and 150. Assuming a western Mediterranean origin the estimate using the chromosomal polymorphism gives an initial sample of 10 to 15 individuals (Brncic et al. 1981; Prevosti et al. 1985). With restriction map analysis, the number of $\mathrm{O}$ chromosomes for the rp49 region that expanded in America was estimated as 8 to 12 (Rozas and Aguade 1991). Using microsatellite data, the estimate gives similar values (4 to 11 individuals; Pascual et al. 2001). The maximum range of colonizers was obtained by joint analysis of chromosomal inversions and lethal genes (10 to 150 individuals; Mestres et al. 1990).

The origin of the colonization The population from which the colonization started must have a genetic structure that fits with the different genetic traits found in the Americas. Specifically, it must contain all the chromosomal inversions and arrangements that are detected in the colonized areas (Prevosti et al. 1985; 1988; 1990), with the exception of those that have arisen there recently: namely $\mathrm{E}_{17}$ (Brncic et al. 1982), $\mathrm{E}_{18}$ (Pegueroles et al. 1988), $\mathrm{E}_{21}$ and $\mathrm{O}_{26}$ (Balanyà et al. 2003), and $\mathrm{E}_{23}$ (Balanyà et al. (2004). The $\mathrm{O}_{5}$ inversion, with a rather erratic distribution in the Palearctic region (Krimbas 1993; Zivanovic and Mestres 2000) is a good landmark for tracing the origin of the American populations. It has non-negligible frequencies in these populations and is distributed according to significant latitudinal clines (Prevosti et al. 1985; 1988; 1990). Furthermore, in spite of being completely associated with a lethal gene it has an heterotic effect (Mestres et al. 2001). A Palearctic population containing an $\mathrm{O}_{5}$ inversion carrying a lethal gene allelic to that found in America and with the same Odh haplotype as that carried by the American $\mathrm{O}_{5}$ inversions, would be a very good candidate for the population from which the colonization started. Palearctic $\mathrm{O}_{5}$ inversions show variability for lethal genes (Mestres et al. 1992; Zivanovic and Mestres 2000) and for Odh nucleotide sequences. The $\mathrm{O}_{5}$ haplotype found in America has also been observed in the $\mathrm{O}_{5}$ inversions from Taulé (France) and Lilla-Edet (Sweden), but not in the $\mathrm{O}_{5}$ inversion from Louvain-la-Neuve (Belgium) which indicates that there is more genetic variability within this arrangement in European populations. The viability and Odh haplotypes of more $\mathrm{O}_{5}$ inversions should be analyzed in order to obtain more information about the population from which the colonization started. This is not an easy task, however, given its low frequency and its rather erratic distribution in the Palearctic area.

Three different Odh haplotypes have been observed in association with American $\mathrm{O}_{3+4+7}$ arrangements. Since these arrangements were most probably included in the sample of chromosomes carried by the colonizers, their frequency in the population of origin should be rather high. It is possible to analyze the distribution of $\mathrm{O}_{5}$ and $\mathrm{O}_{3+4+7}$ arrangements in the Palearctic region (Krimbas 1993) and compare the areas in which they overlap. With this information it has been possible to select those populations in which the $\mathrm{O}_{5}$ inversion and also a non-negligible frequency of $\mathrm{O}_{3+4+7}$ are found. The populations fulfilling this requirement and also having all other chromosomal arrangements found in America are: Mt. Parnes (Greece) when gathering together data from different years (Krimbas 1967; Krimbas and Alevizos 1973); Zürich (Switzerland), in a collection of 720 individuals (Burla and Götz 1965) and in a later collection of 942 individuals (Gosteli 1990); and finally in the Swiss canton of Valais when grouping together the sub-samples collected at different altitudes (Burla et al. 1986). Whilst the frequency of $\mathrm{O}_{3+4+7}$ arrangement ranges between 2.40 and $6.65 \%$ in Mt. Parnes, in the Swiss populations this frequency is negligible $(0.07$ and $0.11 \%$ in Zürich and $0.8 \%$ in canton of Valais). Thus, Greece seems to be the most likely region from which the colonization could have started. Other evidence in favor of this hypothesis is provided by the analysis of the $\mathrm{O}_{3+4+2}$ arrangement. Even though only one haplotype of the $\bar{O} d h$ gene has been detected in all $\mathrm{O}_{3+4+2}$ chromosomal lines studied, in the early analysis some copies of this arrangement that are free of lethals and some carrying the same lethal gene were found in both North and South America. Thus, it is likely that one or at most two $\mathrm{O}_{3+4+2}$ arrangements were included in the original sample of colonizers. Accordingly, the population of origin should contain this arrangement, probably with a frequency lower than that of the $\mathrm{O}_{\underline{3+4+7}}$ arrangement. Again, the population of Mt. Parnes fits all these requirements (Krimbas 1967). Finally, this hypothesized Mediterranean origin of the colonizers is consistent with the pattern of enhanced evolution in Northern latitudes observed by Gilchrist et al. (2001) when analyzing rates of evolution for quantitative traits in colonizing populations of this species.

These interpretations still present some difficulties. The population of Mt. Parnes exhibits a non-negligible frequency of the $\mathrm{O}_{3+4+1}(19.84-28.00 \%)$ and $\mathrm{O}_{3+4+22}(2.38$ - 11.47\%) chromosomal arrangements (Krimbas 1967) and these arrangements have never been found in America. A sample size of 100 individuals should statistically contain both arrangements. Furthermore, later analyses of chromosomal polymorphism in the Greek populations of Mt. Parnes (Sept. 1975 and April 1977), Crete (Sept. 1977) and Preveza (Sept. 1975) did not detect the $\mathrm{O}_{5}$ inversion (Loukas et al. 1979; 1980; 1981). These samples were collected just before the first detection of $D$. subobscura in Puerto Montt (Chile). Mt. Parnes was not the only Greek population in which the $\mathrm{O}_{5}$ inversion was detected. It was also present in the analyses of Athens, 
Poros, Vytina and Cephalonia (Krimbas 1964). In some of them the frequency of $\mathrm{O}_{3+4+1}$ is lower than that recorded in Mt. Parnes and $\mathrm{O}_{3+4+22}$ is absent. Thus, the frequencies of the $\mathrm{O}$ chromosomal arrangements vary on a geographical scale when analyzing different Greek populations. Furthermore, there is evidence of microdifferentiation in one population: Krimbas and Alevizos (1973) found differences in chromosomal polymorphism when comparing different traps. For these reasons a small sample of colonizers from a Greek population (most probably 10 to 15 individuals, as suggested in the previous section) could contain an $\mathrm{O}_{5}$ inversion without the $\mathrm{O}_{\underline{3+4+1}-1}$ or $\mathrm{O}_{3+4+22}$ chromosomal arrangements.

Origin and persistence of the association between the Odh haplotypes and chromosomal arrangements Chromosomal arrangements are considered important substrates for adaptation during colonizing events (Lee 2002). Thus, it is important to recognize, using different genetic markers and their association with chromosomal arrangements, the chromosomes or chromosomal segments that were included in the initial sample of colonizers. The distribution of the Odh haplotypes in the American populations is mainly determined by the distribution of those chromosomal arrangements with which these haplotypes are. This nonrandom association between Odh haplotypes and some chromosomal arrangements can be explained both, by the chromosomal composition of the colonizing sample - in which some arrangements, such as the $\mathrm{O}_{5}$ inversion, were represented only once - and by a lack of free genetic exchange in the $\mathrm{O}_{5}, \mathrm{O}_{2}$ and $\mathrm{O}_{7}$ inversions. On the other hand, the $\mathrm{O}_{3+4}$, $\mathrm{O}_{3+4+8}$ and $\mathrm{O}_{\text {st }}$ arrangements exhibit greater genetic variability; they share some haplotypes, which, as expected, is an indication of the possibility of free genetic exchange since in these arrangement the Odh gene is not included in any inversion. Thus, some or all of these arrangements could be represented more than once in the colonizing sample and/or the Odh gene could exhibit a greater genetic exchange in them since it is located far away from any of their breakpoints. This latter possibility is supported by the data obtained in the Centralia population, which is the most recently collected sample (Solé et al. 2000) and in which the $\mathrm{O}_{\underline{3+4}}, \mathrm{O}_{\underline{3+4+8}}$ and $\mathrm{O}_{\text {st }}$ arrangements are found at higher frequency. Both of these factors favor genetic exchange between these arrangements in this population.

Because the $O d h$ gene does not overlap with any of the $\mathrm{O}_{\underline{3+4}}, \mathrm{O}_{\underline{3+4+8}}$ or $\mathrm{O}_{\text {st }}$ arrangements, it is difficult to assign haplotypes to chromosomal arrangements in this case. They share five haplotypes and many different lethal and normal chromosomes carrying these arrangements could reach the Americas. The Odh gene sequence can be used to estimate the number of copies of a given inversion (or arrangement) if it is located inside or very close to any of its breakpoints. However, it is not useful for those arrangements with breakpoints located far away from the Odh locus. Lethal genes behave in a similar way, showing associations with arrangements in many situations. It would be very useful to have other genetic markers, associated with the $\mathrm{O}_{3+4}$ and $\mathrm{O}_{3+4+8}$ arrangements available to estimate the number of these chromosomes that could be included in the genetic pool of the colonizers. In any case, the initial sample of chromosomes that reached America carried enough genetic variability to allow the establishment of $D$. subobscura and its expansion within both hemispheres.

We thank S. Atrian and T. Luque for their information on Odh and for their help with in situ hybridization. We also thank A. Moya, C. Arenas and G. W. Gilchrist for their comments and suggestions, and R. Rycroft (S.A.L., Universitat de Barcelona) for corrections to the English. This work was supported by grants PB96-0793-C04-03 and BOS2000-0295-C02-02 from the Dirección General de Enseñanza Superior (Spain), BFM2000-1383 from the Ministerio de Ciencia y Tecnología (MCYT; Spain), 2000SGR 00068 and 2001SGR 00207 from the Generalitat de Catalunya (Spain) and GR00-27 from the Conselleria de Cultura i Educació, Comunidad Valenciana (Spain).

\section{REFERENCES}

Andolfatto, P., Depaulis F., and Navarro, A. (2001). Inversion polymorphisms and nucleotide variability in Drosophila. Genet. Res. Camb. 77, 1-8.

Ayala, F. J., Serra, L., and Prevosti, A. (1989). A grand experiment in evolution: the D. subobscura colonization of the Americas. Genome 31, 46-255.

Balanyà, J., Segarra, C., Prevosti, A., and Serra, L. (1994). Colonization of America by D. subobscura: the founder event and a rapid expansion. J. Hered. 85, 427-432.

Balanyà, J., Serra, L., Gilchrist, G.W., Huey, R. B., Pascual, M., Mestres, F., and Solé, E. (2003). Evolutionary pace of chromosomal polymorphism in colonizing populations of $D$. subobscura: an evolutionary time series. Evolution 57, 18371845.

Balanyà, J., Solé, E., Oller, J.M., Sperlich, D., and Serra, L. (2004). Long-term changes in the chromosomal inversion polymorphism of D. subobscura. II. European populations. J. Zool. Syst. Evol. Res. 42, 1-11.

Beckenbach, A. T., and Prevosti, A. (1986). Colonization of North America by the European species, D. subobscura and $D$. ambigua. Am. Mid. Nat. 115, 10-18.

Brncic, D., Budnik, M., and Prevosti, A. (1982). Ordenaciones cromosómicas en las poblaciones chilenas de D. subobscura. Medio Ambiente 6, 23-32.

Brncic, D., Prevosti, A., Budnik, M., Monclús, M., and Ocana, J. (1981). Colonization of D. subobscura in Chile. I. First population and cytogenetic studies. Genetica 56, 3-9.

Burla, H., and Götz, W. (1965). Veränderlichkeit des chromosomalen Polymorphismus bei D. subobscura. Genetica 36, 83-104.

Burla, H., Jungen, H., and Bächli, G. (1986). Population structure of D. subobscura: non-random microdispersion of inversion polymorphism on a mountain slope. Genetica 70, 9-15.

Canestro, C., Albalat, R., Hjelmqvist, L., Godoy, L., Jörnvall, H., and Gonzàlez-Duarte, R. (2001). Ascidian and Anfioxus Adh 
genes correlate functional and molecular features of the ADH family expansion during vertebrate evolution. J. Mol. Evol. 53, 81-89.

de Frutos, R., Kimura, K., and Peterson, K. (1990). In situ hybridization of Drosophila polytene chromosomes with digoxigenin-dUTP labeled probes. Methods Mol. Cell. Biol. 2, 32-36.

Gilchrist, G.W., Huey, R.B., and Serra, L. (2001). Rapid evolution of wing size clines in D. subobscura. Genetica 112113, 273-286.

Gosteli, M. (1990). Chromosomal polymorphism in natural populations of $D$. subobscura near Zürich, Switzerland: a contribution to long-term comparisons. Genetica 81, 199-204.

Hall, T. A. (1999). BioEdit: a user-friendly biological sequence alignment editor and analysis program for Windows 95/98/ NT. Nucleic Acid Series 41, 95-98.

Huey, R. B., Gilchrist, G. W., Carlson, M. L., Berrigan. D., and Serra, L. (2000). Rapid evolution of a geographic cline in size in an introduced fly. Science 287, 308-309.

Krimbas, C. B. (1964). The genetics of D. subobscura populations. I. Inversion polymorphism in natural populations of Southern Greece. Evolution 18, 541-552.

Krimbas, C. B. (1967). The genetics of D. subobscura populations. III. Inversion polymorphism and climatic factors. Mol. Gen. Genet. 99, 133-150.

Krimbas, C. B. (1993). D. subobscura: Biology, Genetics and Inversion Polymorphism. Verlag Dr. Kovac, Hamburg.

Krimbas, C. B., and Alevizos, V. (1973). The genetics of D. subobscura populations. IV. Further data on inversion polymorphism in Greece - evidence of microdifferentiation. Egypt. J. Genet. Cytol. 2, 121-132.

Krimbas, C. B., and Loukas, M. (1980). The inversion polymorphism of D. subobscura. Evol. Biol. 12, 163-234.

Kumar, S., Tamura, K., Jakobsen, I. B., and Nei, M. (2001). MEGA2: Molecular Evolutionary Genetics Analysis software. Bioinformatics 17, 1244-1245.

Kunze-Müh, E., and Müller, E. (1958). Weitere Untersuchungen über die chromosomale Struktur und die natürlichen Strukturtypen von D. subobscura. Chromosoma 9, 559-570.

Latorre, A., Moya, A., and Ayala, F. J. (1986). Evolution of mitochondrial DNA in D. subobscura. Proc. Natl. Acad. Sci. USA 83, 8649-8653.

Lee, C. E. (2002). Evolutionary genetics of invasive species. Trends Ecol. Evol. 17, 386-391.

Lindsley, D. L., and Zimm G. G. (1992). The genome of $D$. melanogaster. Academic Press Inc., San Diego.

Loukas, M., Krimbas, C. B., and Vergini, Y. (1979). The genetics of $D$. subobscura populations. IX. Studies on linkage disequilibrium in four natural populations. Genetics 93, 497523.

Loukas, M., Krimbas, C. B., and Morgan, K. (1980). The genetics of D. subobscura populations. XIV. Further data on linkage disequilibria. Genetics 95, 757-768.

Loukas, M., Vergini, Y., and Krimbas, C. B. (1981). The genetics of D. subobscura populations. XVII. Further genetic heterogeneity within electromorphs by urea denaturation and the effect of the increased genic variability on linkage disequilibrium studies. Genetics 97, 429-441.

Luque, T., Atrian, S., Danielsson, O., Jörnvall, H., and GonzàlezDuarte, R. (1994). Structure of the D. melanogaster glutathione-depedent formaldehyde dehydrogenase/octanol dehydrogenase gene (class III alcohol dehydrogenase). Eur. J. Biochem. 225, 985-993.

Marchuck, D., Drumm, M., Saulino, A., and Collins, F. S. (1992). Construction of T-vectors, a rapid general system fir direct cloning of unmodified PCR product. Nucleic Acids Res. 19, 1154.

Mestres, F., and Serra, L. (1995). On the origin of the $\mathrm{O}_{5}$ chromosomal inversion in American populations of $D$. subobscura. Hereditas 123, 39-46.

Mestres, F., and Serra, L. (1999). Distribution of lethal genes and their allelism in the $\mathrm{O}$ chromosome of D. subobscura. J. Zool. Syst. Evol. Res. 37, 7-11.

Mestres, F., Sanz, J., and Serra, L. (1998). Chromosomal structure and recombination between inversions in $D$. subobscura. Hereditas 128, 105-113.

Mestres, F., Serra, L., and Ayala, F. J. (1995). Colonization of the Americas by D. subobscura. Lethal-gene allelism and association with chromosomal arrangements. Genetics 140, 1297-1305.

Mestres, F., Pegueroles, G., Prevosti, A., and Serra, L. (1990). Colonization of America by D. subobscura: Lethal genes and the problem of the $\mathrm{O}_{5}$ inversion. Evolution 44, 1823-1836.

Mestres, F., Balanyà, J., Arenas, C., Solé, E., and Serra, L. (2001). Colonization of America by D. subobscura: Heterotic effect of chromosomal arrangements revealed by the persistence of lethal genes. Proc. Natl. Acad. Sci. USA 98, 91679170.

Mestres, F., Balañà, J., Segarra, C., Prevosti, A., and Serra, L. (1992). Colonization of America by D. subobscura: Analysis of the inversions from Europe and America and their implications for the colonizing process. Evolution 46, 15641568.

Mestres, F., Balañà, J, Segarra, C., Prevosti, A., Serra, L. (1994). O chromosome inversion polymorphism in Northern and Atlantic Europe and its implications in the American colonization by D. subobscura. Z. Zool. Syst. Evolut.-forsch 32, $108-116$.

Munté, A., Aguadé, M., and Segarra, C. (2000). Nucleotide variation at the yellow gene region is not reduced in $D$. subobscura: A study in relation to chromosomal polymorphism. Mol. Biol. Evol. 17, 1942-1955.

Noor, M. A. F., Pascual, M., and Smith, K. R. (2000). Genetic variation in the spread of $D$. subobscura from a non equilibrium population. Evolution 54, 696-703.

Pascual, M., Aquadro, C. F., Soto, V., and Serra, L. (2001). Microsatellite variation in colonizing and Palearctic populations of $D$. subobscura. Mol. Biol. Evol. 18, 731-740.

Pegueroles, G., Mestres, F., and Serra, L. (1996). Analysis of inbreeding in a colonizing population of $D$. subobscura. Genetica 80, 39-43.

Pegueroles, G., Segarra, C., and Prevosti, A. (1988). A new inversion of the $\mathrm{E}$ chromosome in D. subobscura. Dros. Inform. Serv. 67, 64-65.

Pegueroles, G., Mestres, F., Argemí, M., and Serra, L. (1999). Phenotypic plasticity in colonizing populations of $D$. subobscura. Genetics and Molecular Biology 22, 511-516.

Pegueroles, G, Papaceit, M., Quintana, A., Guillén, A., Prevosti, A., Serra, L. (1995). An experimental study of evolution in progress: clines for quantitative traits in colonizing and Palearctic populations of Drosophila. Evol. Ecol. 9, 453465.

Prevosti, A., García, M. P., Serra, L., Aguadé, M., Ribó, G., and Sagarra, E. (1983). Association between allelic isozyme alleles and chromosomal arrangements in European populations and Chilean colonizers of $D$. subobscura. Isozymes 10, 171-191.

Prevosti, A., Serra, L., Segarra, C., Aguadé, M., Ribó, G., and Monclús, M. (1990). Clines of chromosomal arrangements of D. subobscura in South America evolve closer to Old World 
patterns. Evolution 44, 218-221.

Prevosti, A., Ribó, G., Serra, L., Aguadé, M., Balanyà, J., Monclús, M., Mestres, F. (1988). Colonization of America by $D$. subobscura: experiment in natural populations that supports the adaptive role of chromosomal-inversion polymorphism. Proc. Natl. Acad. Sci. USA 85, 5597-5600.

Prevosti, A., Serra, L., Aguadé, M., Ribó, G., Mestres, F., Balañà, J., and Monclús, M. (1989). Colonization and establishment of the Palearctic species D. subobscura in North and South America. In: Evolutionary Biology of Transient Unstable Populations (ed.: A. Fontdevila), pp. 114-129. Springer-Verlag: Berlin.

Prevosti, A., Serra, L., Ribó, G., Aguadé, M., Sagarra, E., Monclús, M., and García, M. P. (1985). The colonization of $D$. subobscura in Chile. II. Clines in the chromosomal arrangements. Evolution 39, 838-844.

Rozas, J., and Aguadé, M. (1991). Using restriction-map analysis to characterize the colonization process of $D$. subobscura on the American continent. I. rp49 region. Mol. Biol. Evol. 8, 447-457.

Rozas, J., and Aguadé, M. (1994). Gene conversion is involved in the transfer of genetic information between naturally occurring inversions of Drosophila. Proc. Natl. Acad. Sci. USA 91, 11517-11521.

Rozas, J., and Rozas, R. (1999). DnaSP version 3: an integrated program for molecular population genetics and molecular evolution analysis. Bioinformatics 15, 174-175.
Rozas, J., Hernández, M., Cabrera, V.M., and Prevosti, A. (1990) Colonization of America by D. subobscura: Effect of the founder event on the mitochondrial DNA polymorphism. Mol. Biol. Evol. 7, 103-109.

Rozas, J., Segarra, C., Ribó, G., and Aguadé, M. (1999). Molecular population genetics of the $r p 49$ gene region in different chromosomal inversions of D. subobscura. Genetics 151, 189-202.

Saitou, N., and Nei, M. (1987). The neighbor-joining method: a new method for reconstructing phylogenetic trees. Mol. Biol. Evol. 4, 406-425.

Solé, E., Mestres, F., Balanyà, J., Arenas, C., and Serra, L. (2000). Colonization of America by D. subobscura: spatial and temporal lethal-gene allelism. Hereditas 133, 65-72.

Sperlich, D., Feuerbach-Mravlag, H., Lange, P., Michaelidis, A., and Pentzos-Daponte, A. (1977). Genetic load and viability distribution in central and marginal populations of $D$. subobscura. Genetics 86, 835-848.

Visa, N,, Marfany, G., Vilageliu, L., Albalat, R., Atrian, S., and Gonzàlez-Duarte, R. (1991). The Adh in Drosophila: chromosomal location and restriction analysis in species with different phylogenetic relationships. Chromosoma 100, 315322.

Zivanovic, G., and Mestres, F. (2000). Lethal genes in $\mathrm{O}_{5}$ chromosomes of $D$. subobscura from Europe and America. J. Zool. Syst. Evol. Res. 38, 123-126. 